\title{
The Value of Fresh-stripped Topsoil as a Source of Useful Plants for Surface Mine Revegetation
}

\section{GENE S. HOWARD AND MARILYN J. SAMUEL}

\section{Abstract}

Topsoil from nearby undisturbed areas was stripped and directly laid over regraded overburden to a depth of about $20 \mathrm{~cm}$ at Kemmerer, Wyo., and Oak Creek, Colo. Native plant response was determined after two growing seasons with only natural precipitation. Rhizomatous species were the most valuable for establishing the perennial plants. Plant density averaged 4.16 and 1.77 plants $/ \mathrm{m}^{2}$ at Kemmerer and Oak Creek sites, respectively, but the density was too low to meet State and Federal revegetation standards without additional seeding. Plants established from fresh-stripped topsoil are a plus in revegetation as opposed to stockpiled topsoil where these plants are lost.

Rangeland topsoil contains seed, rhizomes, and other vegetative plant parts of many native species. Beauchamp et al. (1975), who studied Wyoming topsoil as a seed source for reseeding stripmine spoils, concluded that viable seed of desirable species was plertiful in the top 2 inches of soil. However, they indicated that seeding or transplanting of desired species would also be required to meet State reclamation standards. Knipe and Springfield (1972), working in New Mexico, found that natural reproduction from seed of desirable range

Authors are horticulturist and botanist, respectively. Department of AgricultureScience and Fducation Administration. High Plains Crassland Research Staton. Cheyenne. Wyoming 82001 .

This study is a contribution from SEA - AR, U.S. Dep. Agr. in cooperation with the Wyoming Agricultural txperiment Station, Untversity of Wyoming. Laramie. It was supported in part by the Environmental Protection Agency lnteragency Agreement Funds: EPA-IAG-D5-E763.

Minuscript received February 8.1978 plants was subject to high loss by wind, water, animals, or insects, and unfavorable conditions for seedling establishment, thus limiting natural reseeding of disturbed lands.

A survey was conducted in fall 1977 at two locations to determine species establishment and plant density on spoils that were topsoiled in 1976 with fresh-stripped topsoil.

\section{Study Area}

Study areas were located at the Kemmerer Coal Co. near Kemmerer, Wyo., and the Pittsburg and Midway Coal Co. near Oak Creek, Colo.

Elevation at the Kemmerer site is about 2,317 $\mathrm{m}$. The experimental topsoil came from a big sagebrush (Artemisia tridentata) plant community. Major plant species included western wheatgrass ( $A g r o$ Pron smithii), slender whealgrass (A. trachycaulum), big sagebrush, fourwing saltbush (Atriplex canescens), and Indian ricegrass (Oryzops is hymenoides). The average annual precipitation at Kemmerer is $23.52 \mathrm{~cm}$. Topsoil at Kemmerer is a Ustic torriorthent with a clayey, mon morillinitic calcareous, frigid, shallow family and loamy, skeleat mixed calcareous family. The slope is about $15 \%$.

AtOak Creek the elevation is about $2,286 \mathrm{~m}$. The topsoil came from a mix-shrub plant community. Major plant species were saskatoon serviceberry (Amelanchier alnifolia), gambels oak (Quercus gam. beli), quaking aspen ( $P$ opulus tremuloides), big sagebrush, snowberry (Symphoricarpos albus), chokecherry (Prunus virginiana), and mountain brome (Bromus marginatus). The average annual precipitation at Yampa, Colo. which is $13 \mathrm{~km}$ south of the Oak Creek site, is about $39.37 \mathrm{~cm}$. The topsoil at Oak Creek is an unnamed complex 
having a slope of about $25 \%$.

\section{Materials and Methods}

In spring 1976, topsoil from nearby undisturbed areas was stripped with earthmovers and immediately spread as uniformly as possible over reclaimed overburden to a depth of about $20 \mathrm{~cm}$ at each site. Topsoil was stripped at Kemmerer to depths of 10 to $60 \mathrm{~cm}$ and at Oak Creek to depths of 45 to $60 \mathrm{~cm}$.

On June 16, 1977, at Kemmerer and on June 29, 1977, at Oak Creek, all plant species within the topsoiled plots were listed to determine plant establishment after spring seed germination. On September 26 at Oak Creek and on September 27 at Kemmerer, quadrats along transects were laid out within the topsoiled plots. At Kemmerer, six transects were randomly located in each of six plots (6 $\mathrm{m}$ wide by $69 \mathrm{~m}$ long for a total of $414 \mathrm{~m}$ ). At Oak Creek, six transects were randomly located in each of 6 plots ( $7 \mathrm{~m}$ wide by $46 \mathrm{~m}$ long for a total of $276 \mathrm{~m}$ ). Populations of species were counted along the transects at .9-m intervals. We counted 450 quadrats at Kemmerer and 300 quadrats at Oak Creek. Tillers were counted for rhizomatous species, and plants were counted for the other species.

\section{Results and Discussion}

Precipitation for the 16 months preceding the plant density survey was about 12.62 and $27.94 \mathrm{~cm}$ for Kemmerer and Oak Creek, respectively.

Despite drouth conditions, we found 39 species growing in the new topsoil at Kemmerer, about 14 months after treatment. At Oak Creek, we found 41 species. Most of these species did not survive over summer and were not counted in September. Hence they only have been transitory or too few to be significant in disturbed-land reclamation.

The topsoiled plot and an adjacent overburden experimental plot at Oak Creek were densely covered with Russian thistle (Salsola kali). Seed was probably transported by wind from nearby areas.

Table 1 gives the density, as determined by the quadrat survey, from the Kemmerer and Oak Creek areas. The density of grasses was greater at Kemmerer than at Oak Creek, probably because of the rhizomatous habit of western wheatgrass. The density of perennial forbs was also greater at Kemmerer than at Oak Creek, whereas the density of woody shrubs was the same at both sites.

\section{Conclusions}

Topsoil that is stripped in early spring and immediately spread is a good source for some useful reclamation plants. In arid regions, this source is important, not so much as a seed source as for the transfer of rhizomes and other vegetative plant parts that will grow after they are moved. The value of certain rhizomatous species is shown by their survival at Kemmerer, despite the low precipitation, as compared with the lower survival of all plant types at Oak Creek, which had about twice the precipitation. The lower survival at Oak Creek may be attributed to a different plant community as well as to drouth conditions during the test period.

The average plant density, for all perennial species, was 4.16 plants $/ \mathrm{m}^{2}$ at Kemmerer and 1.77 plants $/ \mathrm{m}^{2}$ at Oak Creek. This is not an adequate plant population to meet State and Federal revegetation standards. However, these native plants may serve as seed and hizome sources for increased plant density in later favorable years. Seeding of range species or irrigating sites during the establishment in September, 1977.

\begin{tabular}{|c|c|c|c|}
\hline Species & Common name & Kemmerer & Oak Creek \\
\hline \multicolumn{4}{|l|}{ Perennial Grasses } \\
\hline \multicolumn{4}{|l|}{ Agropyron smithii var. } \\
\hline molle* & Western wheatgrass & 2.19 & - \\
\hline Agrostis scabra & Rough bent & .15 & - \\
\hline Bromus marginatus & Mountain brome & - & .66 \\
\hline Elymus cinereus & Basin wildrye & .18 & - \\
\hline Poa arida* & Plains bluegrass & .52 & .70 \\
\hline Total & & 3.04 & 1.36 \\
\hline \multicolumn{4}{|l|}{ Perennial Forbs } \\
\hline \multicolumn{4}{|l|}{ Achillea millefolium } \\
\hline lanulosa* & Common yarrow & .19 & .03 \\
\hline Aster engelmanni* & Engelmann aster & .75 & - \\
\hline Cirsium drummondi & Drummond thistle & $\cdots$ & .04 \\
\hline Meliolotus officinalis & Sweet clover & - & .04 \\
\hline Vicia americana* & American vetch & - & .04 \\
\hline Viguiera multiflora & Showy goldeneye & - & .08 \\
\hline Total & & .94 & .23 \\
\hline \multicolumn{4}{|l|}{ Woody Shrubs } \\
\hline $\begin{array}{l}\text { Artemisia tridentata } \\
\text { Chrysothamnus }\end{array}$ & Big sagebrush & .08 & .08 \\
\hline viscidiflorus & Douglas rabbitbrush & .05 & - \\
\hline Rosawoodsii & Woods rose & .02 & - \\
\hline Symphoricarpos albus & Common snowberry & .03 & .10 \\
\hline Total & & .18 & .18 \\
\hline Total of the 3 above $g$ & groups: & 4.16 & 1.77 \\
\hline \multicolumn{4}{|l|}{ Annuals } \\
\hline $\begin{array}{l}\text { Capsella bursa- } \\
\text { pastoris }\end{array}$ & Shepherdspurse & .15 & - \\
\hline Chenopodium album & Lambsquarter goosefoot & - & .02 \\
\hline C. strictum & --- goosefoot & .27 & - \\
\hline Hordeum jubatum & Foxtail barley & - & .03 \\
\hline Kochia scoparia & $\begin{array}{l}\text { Belvedere summer- } \\
\text { cypress }\end{array}$ & 72.68 & - \\
\hline Lactuca scariola & Wild lettuce & - & .07 \\
\hline Lappula redowski & Common stickseed & - & .28 \\
\hline Moldavica parviflora & Dragonhead & - & .13 \\
\hline Polygonum aviculare & Prostrate knotweed & .03 & .04 \\
\hline Salsola kali & Russian thistle & 88.0 & 952.0 \\
\hline
\end{tabular}

*rhizomatous

period should enhance adequate revegetation at the Kemmerer site. Seeding selected species would probably suffice at Oak Creek, where precipitation is not so limited.

\section{Literature Cited}

Beauchamp, H., R. Lang, and M. May. 1975. Topsoil as seed source for reseeding strip mine spoils. Univ. of Wyoming, Agr. Exp. Sta., Res. J. 90.8 p.

Knipe, O.D., and H.W. Springfield. 1972. Germinable alkali sacaton seed content of soils of the Rio Puerco Basin, West Central New Mexico. Ecology 53 (5): 965-968. 